\title{
ANALISIS PERKEMBANGAN DAN ELASTISITAS TRANSMISI HARGA ABALON (HALIOTIS ASININA) DI KABUPATEN BUTON
}

\author{
Endryawan \\ Mahasiswa Program Magister Agribisnis, Program Pascasarjana, \\ Universitas Halu Oleo, Kendari, Sulawesi Tenggara \\ Email : endryawan22@gmail.com \\ Azhar Bafadal \\ Idrus Salam \\ Program Magister Agribisnis Universitas Halu Oleo, Kendari \\ Email : azharbafadal@yahoo.com\&idrusssalam030897@yahoo.com
}

\begin{abstract}
This study aims to analyze the prize development and the price transmission elasticity of abalone in Buton Regency. This study was conducted in June - July 2015 with a survey method. Analysis of price developments and elasticity of price transmission is done by a simple linear regression model. The results showed that each added one period, abalone prices decreased by Rp. 9501 each kilogram. Pricetransmission elasticity show in the level consumers prices has been not fully transmitted to the level of fisherman with vale ofelasticityis 0,11 indicated that when the selling pricein the level consumers increased by $1 \%$ then the selling pricein the levelfisherman will increase of $0,11 \%$, or moere easly can be defined that if the selling pricein the level consumers increase, the selling pricein the levelfisherman will also be increase.
\end{abstract}

Key words: Abalone, Marketing Channels, Prize Development, Price Transmission Elasticity

QE Journal | Vol.04 - No.02 June 2015 - 83 


\section{PENDAHULUAN}

roduksi perikanan laut Indonesia sampai saat ini masih didominasi
ekil tangkapan alam, sebagai komoditas pasar lokal maupun
ekspor. Hasil produksi tersebut sebagian besar didominasi oleh
jenis-jenis ikan, seperti ikan tuna(Thunus sp.), cakalang (Katswonus
pelamis), ikan kerapu(Lutjanus sp.), dan sebagainya. Kekerangan sebagai salah satu komoditas perikananmerupakan potensi yang belum dikelola dan dimanfaatkan secara optimal.Mayoritas produksi kekerangan yang ada hanya digunakan untuk konsumsi sendiri (kerang pasir, siput mata bulan, dan siput berukuran kecil lainnya), sebagian dijual untuk konsumsi lokal (kerang darah, kerang hijau, kerang bakau dan oyster), dan hanya sebagian kecil untuk diekspor (batu laga, lola, kima, dan abalon) (Setyono, 2007).

Abalon termasuk komoditas perikanan yang memiliki nilai ekonomi tinggi (Leigthon, 2008).Pada tahun 2004 nilai ekonomi abalon di tingkat nelayan adalah sekitar US\$ 15 per $\mathrm{kg}$ dan meningkat sampai US\$ 30 per kg pada tahun 2010 (Setyono, 2004; Setyono, 2010). Permintaan abalon di beberapa negara seperti Eropa, Amerika, dan Asia (Cina, Korea, Taiwan dan Jepang) terus meningkat dan menjadi komoditas ekpor unggulan (Setyon, 2009). Kebutuhan abalon dunia selama dua dasawarsa terakhir meningkat sejalan dengan meningkatnya kebutuhan keanekaragaman sumber protein. Peningkatan kebutuhan konsumsi dalam negeri dan ekspor, bahkan telah memicu perkembangan budidaya abalon (Litaay, 2005; Setyono, 2007).

Hasi survei awal wilayah pesisir pantai Sulawesi Tenggara, ditemukanbeberapa tempat yang masyarakatnelayannyatelah melakukan pemanfaatansumberdaya abalon. Beberapa tempat yang dimaksud yaitu Kabupaten Bombana (Kasipute), Kabupaten Konawe (Kecamatan Soropia), Kabupaten Buton (Kecamatan Wabula),Kabupaten Muna Barat (Kecamatan Maginti) dan Kota Bau-Bau (Pulau Makasar). Hasil penelusuran pada keempat lokasi tersebut menunjukkan bahwa hanya Kabupaten Buton masih dijumpai kegiatan pemanfaatan abalon.

Nelayan penangkap merupakan satu-satunya produsen abalon di Kabupaten Buton. Di tingkat nelayan harga jual abalon belum dapat memberikan keuntungan yang maksimal. Produksi nelayan selain dipasarkan di dalam negeri, juga diekspor ke beberapa negara asia seperti 
Cina, Jepang, Korea dan Taiwan (Setyono, 2009). Dengan kondisi tersebut maka seharusnya pemasaran abalon dapat meningkatkan kesejahteraan para pelaku yang terlibat khsushnya nelayan.

Hubungan antara konsumen dan produsen abalon biasanya dijembatani olehpelaku pemasaran atau pedagang yang mempertemukannya dalam suatu sistem pasar. Pedagang melakukan kegiatan pemasokan produk menurut, tempat, waktu, dan kualitas yang disesuaikan dengan kebutuhan konsumen dan penawaran yang dilakukan nelayan.Peran sebagai pedagang memiliki dua fungsi mendasar yaitu sebagai konsumen antara dan sebagai produsen. Sebagai konsumen antara pedagang menurunkan permintaan konsumen kepada produsen, sedangkan sebagai produsen antara pedagang meneruskan penawaran produsen kepada konsumen.

Nelayan sebagai salah satu pelaku agribisnis abalon memiliki posisi yang lemah diantara para pelaku lainnya. Kondisi tersebut terlihat dari modal dan informasi pasar nelayan yang terbatas. Informasi mengenai penurunan harga jual lebih cepat sampai ke tingkat nelayan dibandingkan informasi mengenai kenaikan harga jual. Tinggi rendahnya harga yang diterima nelayan abalon,erat kaitannya dengan jumlah lembaga pemasaran abalon yang terlibat. Pedagang abalon yang jumlahnya sedikit, diduga memonopoli pembelian hasil produksi nelayan. Penentuan harga jual ditingkat nelayan selalu ditentukan oleh pedagang perantara. Kondisi tersebut menyebabkan nelayan abalon tidak lagi memiliki posisi tawar menawar yang kuat.

Informasi perkembangan harga yang didapat diharapkan akan mempermudah produsen dalam merencanakan kegiatan produksi dan pemasaran abalon. Oleh karena itu perlu dilakukan kajian lebih lanjut pada perkembangan harga dan efisiensi pemasaran abalon.

Nelayan sebagai produsen hanya berperan sebagai penerima harga dan tidak mampu mengakses fluktuasi harga pasar. Kondisi tersebut menyebabkan harga abalon ditingkat konsumen tidak sepenuhnya ditransmisikan ke tingkat nelayan atau produsen. Oleh karena itu, perkembangan harga ditingkat penampung besar selaku perantara nelayan dan konsumen harus dapat diprediksi untuk mengantisipasi fluktuasi harga.

QE Journal | Vol.04 - No.02 June 2015 - 85 


\section{METODE PENELITIAN}

Penelitian dilaksanakan pada bulan Juni - Juli 2015 dengan memilih sampel di Desa Bajo Bahari Kecamatan Wabula Kabupaten Buton dan Kota Bau-Bau. Daerah tersebut dipilih karena merupakan sentra penangkapan abalon dan alur perdagangan komoditas laut khususnya abalon. Penelitian ini dilaksanakan dengan metode survey. Data primer dikumpulkan melalui wawancara dengan kuesioner terstruktur terhadap responden sebanyak 35 orang, yang terdiri dari 30 orang nelayan, 3 orang pedagang pengumpul desa dan 2 orang pedagang antar pulau. Data sekunder dikumpulkan dari berbagai dinas/instansi terkait seperti Dinas Perikanan, Badan Pusat Statistik dan literatur yang relevan dengan penelitian.

\section{Analisis Perkembangan Harga}

Data yang digunakan dalam analisis ini adalah data time series Januari 2013- Juli 2015. Analisis perkembangan harga dilakukan dengan metode linear sederhana, dengan persamaan garis trend menurut Kuncoro (2008) berikut :

$$
\mathrm{Y}=\mathrm{a}+\mathrm{bT}
$$

Keterangan :

$\mathrm{Y}=$ Nilai trend periode tertentu

$\mathrm{a}=$ Nilai konstanta

$\mathrm{b}=$ Koefisien arah garis trend

$\mathrm{T}=$ Unit periode yang dihitung

Garis trend dapat digunakan untuk meramal atau mengestimasi apabila koefisien a dan $b$ telah diketahui. Nilai a dan nilai $b$ dapat dihitung dengan persamaan normal sebagai berikut berikut :

$$
\mathrm{a}=\frac{\sum \mathrm{Y}}{\mathrm{n}} \quad \mathrm{b}=\frac{\sum \mathrm{TY}}{\sum \mathrm{T}^{2}}
$$

Keterangan :

$\mathrm{Y}=$ Nilai trend periode tertentu

$\mathrm{a}=$ Nilai konstanta

$\mathrm{b}=$ Koefisien arah garis trend

$\mathrm{T}=$ Unit periode yang dihitung

$\sum \mathrm{Y}=$ Penjualan nilai hasil observasi 
$\Sigma \mathrm{T}=$ Penjumlahan unit waktu yang dihitung

$\mathrm{n} \quad=$ Jumlah periode waktu

Untuk mempermudah perhitungan nilai $\mathrm{T}$ atau $\mathrm{X}$ diberikan skor atau kode. Pada penelitian ini jumlah data (bulan) ganjil, sehingga nilai $T$ pada bulan yang berada ditengah diberi angka 0 , tahun-tahun sesudahnya berturutturut 1, 2, 3, dan seterusnya, sedangkan tahun-tahun sebelumnya berturutturut $-1,-2,-3$, dan seterusnya (Assauri, 1991).

\section{Elastisitas Transmisi Harga}

Eelastisitas transmisi harga menggunakan regresi linear sederhana. Koefisien regresi (b) digunakan untuk mengetahui hubungan atau besarnya pengaruh perubahan harga ditingkat produsen dengan tingkat konsumen. Elastisitas transmisi harga dihitung menurut persamaan Priyadi $d k k$. (2004) sebagai berikut :

$$
\mathrm{E}_{\mathrm{t}}=\frac{1}{\mathrm{~b}} \times \frac{\mathrm{P}_{\mathrm{f}}}{\mathrm{P}_{\mathrm{r}}}
$$

Keterangan :

$\mathrm{E}_{\mathrm{t}}=$ Elastisitas transimisi harga

$\mathrm{b}=$ Koefisien regresi

$\mathrm{P}_{\mathrm{f}}=$ Harga rata-rata ditingkat nelayan $(\mathrm{Rp} / \mathrm{kg})$

$\mathrm{P}_{\mathrm{r}}=$ Harga rata-rata ditingkat konsumen $(\mathrm{Rp} / \mathrm{kg})$

Kriteria pengukuran analisis elastisitas transmisi harga menurut Hasyim (2003):

a. $E_{t}=1$, berarti laju perubahan harga ditingkat produsen sama dengan laju perubahan harga ditingkat konsumen. Menandakan bahwa sistem pemasaran yang berlangsung telah efisien.

b. $E_{t}>1$, berarti laju perubahan harga ditingkat produsen lebih besar daripada laju perubahan harga ditingkat konsumen. Menandakan sistem pemasaran yang berlangsung tidak efisien.

c. $\mathrm{E}_{\mathrm{t}}<1$, berarti laju perubahan harga ditingkat produsen lebih kecil daripada laju perubahan harga ditingkat konsumen. Menandakan sistem pemasaran yang berlangsung tidak efisien. 


\section{HASIL DAN PEMBAHASAN}

\section{Analisis Perkembangan Harga}

Perkembangan harga abalon di Kabupaten Buton dianalisis dengan metode analisis trend menggunakan model regresi linear sederhana. Variabel yang dianalisis yaitu waktu (bulan) sebagai variabel bebasatau independent dan harga jual abalon sebagai variabel terikat atau dependent.

Jumlah produksi abalon di Kabupaten Buton digambarkan berdasarkan data penjualan rata-rata dari pedagang pengumpul desa. Data penjualan pada tingkat pedagang antar pulau tidak digunakan, karena pedagang antar pulau melakukan pembelian abalon dari wilayah lain selain Kabupaten Buton. Data rata-rata penjualan abalon pada tingkat pedagang pengumpul desa dari bulan November 2014 sampai Agustus 2015 dapat dilihat pada Gambar 1.

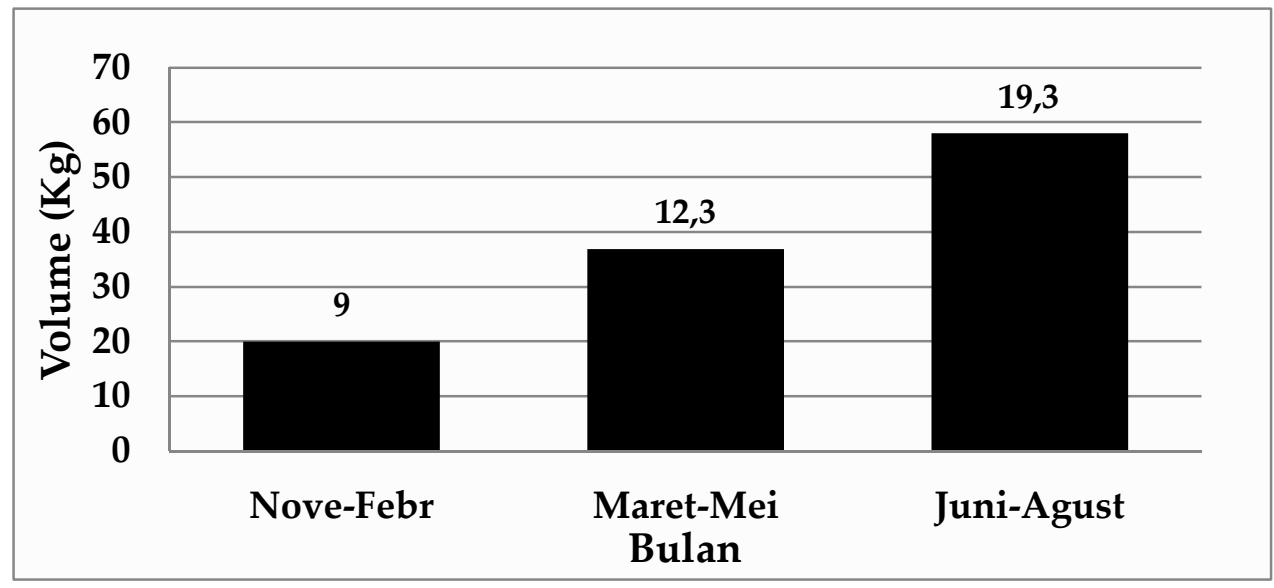

Gambar 1. Volume Penjualan Pedagang Pengumpul Abalon di Desa Bajo Bahari Kecamatan Wabula Kabupaten Buton (November 2014 - Agustus 2015)

Gambar 1 menunjukkan volume penjualan abalon di tingkat pedagang pengumpul pada bulan November 2014 sampai Februari 2015 relatif lebih sedikit dibandingkan volume penjualan pada bulan Maret-Mei danJuniAgustus 2015. Kondisi tersebut erat kaitannya dengan musim penangkapan abalon dan produksi yang dihasilkan nelayan penangkap. 
Produksi nelayan masih bergantung dari hasil tangkapan alam menyebabkan jumlah produksi abalon cenderung akan mengikuti musim penangkapannya. Pada bulan JunisampaiAgustus merupakan musim puncak dengan jumlah abalon yang ditangkap nelayan mengalami peningkatan dan bulan November sampai Desember memasuki musim paceklik dimana hasil tangkapan nelayan relatif menurun.

Berdasarkan hasil penelitian, data menunjukkan perkembangan harga abalonmenunjukkan kecenderungan trend menurundan meningkat pada bulan-bulan tertentu (Gambar 1).Pada gambar tersebut terlihat pada sekitar bulan Januari sampai Maret harga cenderung meningkat. Pada Januari sampai Maret jumlah supply abalon kepada pedagang antar pulau mengalami penurunan (musim paceklik). Kondisi tersebut disebabkan oleh jumlahabalon yang dipasarkan relatif sedikit sehingga menyebabkan naiknya harga akibat mekanisme pasar. Hal ini mengindikasikan jumlah hasil tangkapan nelayan sangat berperan penting dalam mempengaruhi fluktuasi harga abalon. Pada bulan November sampai Maret pembelian pedagang antar pulau hanya mampu mencapai 20 sampai 30 kilogram, sedangkan permintaan dari abalon eksportirmeningkat yang nampak dari kesanggupan eksportir untuk membeli berapapun abalon yang mampu dijual oleh pedagang antar pulau. Trend harga abalon dapat dilihat pada Gambar 2.

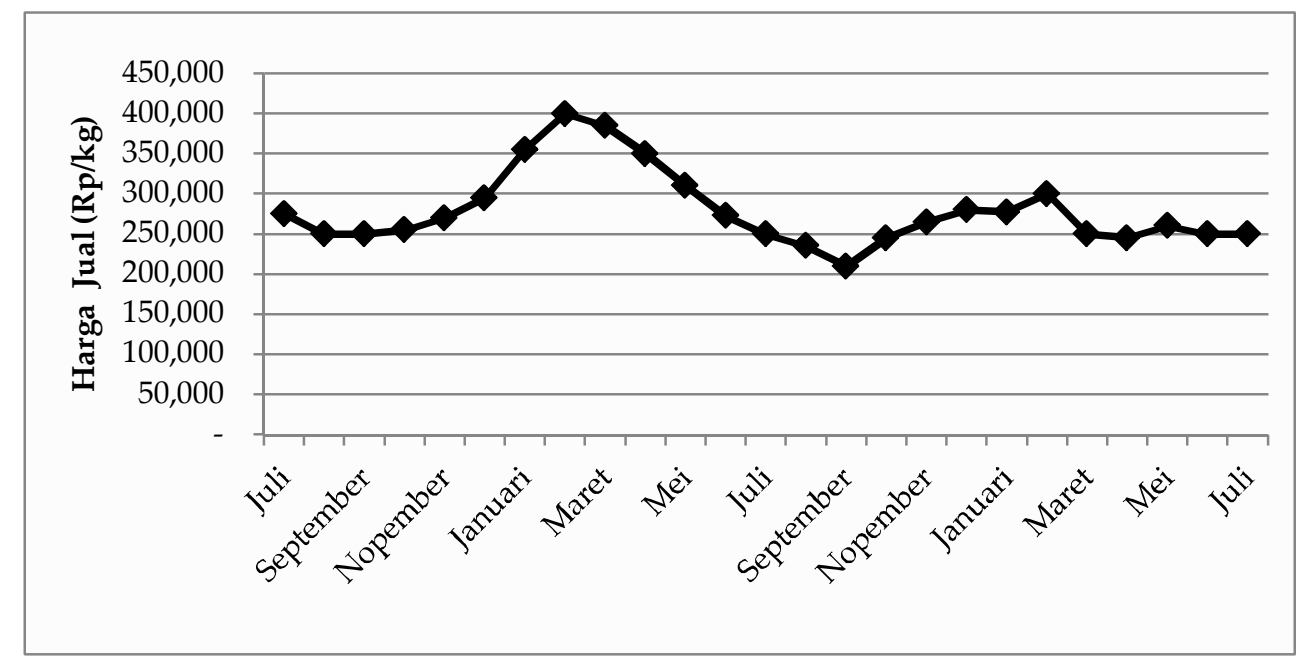

Gambar 2.Trend Perkembangan Harga Jual Abalon di Kabupaten Buton (Periode Juli 2014- Juli 2015) 
Gambar 2 menunjukkan bahwa perkembangan harga abalon di Kabupaten Buton berubah seiring pola musiman yang terbentuk. Jika dilihat dari perkembangan harga tiap bulannya, harga abalon pada bulan April sampai Juni cenderung lebih stabil. Hal ini disebabkan karena produksi abalon dan permintaan cenderung stabil. Meskipun perubahan harga tidak begitu signifikan pada bulan tersebut tetapi ada kecenderungan mengalami trend penurunan harga selama periode tahun 2014 sampai tahun 2015. Peningkatan harga yang paling signifikan terjadi pada bulan Januari sampai Maret tiap tahunnya. Pada bulan tersebut permintaan terhadap abalon meningkat dikarenakan produksi nelayan yang menurun. Produksi nelayan yang masih mengandalkan hasil tangkapan dari alam menyebabkan supply abalon bergantung dari musim penangkapan. Sehingga meskipun harga tinggi nelayan tidak dapat meningkatkan produksinya. Khusus pada bulan Februari peningkatan harga terjadi disebabkan karena bersamaan dengan perayaan tahun baru Cina. Negara Cina merupakan tujuan utama ekspor abalon dari Indonesia. Konsumsi abalon mengalami peningkatan pada saat perayaan tersebut.

Fluktuasi harga yang tinggi menyebabkan penerimaan dan keuntungan usaha yang diperoleh nelayan dari hasil kegiatan usahanya akan sangat berfluktuasi. Kondisi demikian tidak kondusif bagi pengembangan agribisnis abalon karena keuntungan yang diperoleh dari kegiatan agribisnis menjadi tidak stabil padahal tingkat keuntungan yang tinggi dan stabil umumnya justru merupakan daya tarik utama bagi pelaku bisnis untuk melakukan investasi dan memperluas usahanya.Perubahan harga abalon terjadi ketika kurangnya pasokan yang sampai ke pembeli, sebagai akibat dari produksi yang menurun. Nelayan penangkap sebagai produsen utama abalon tidak menjadikan abalon sebagai target utama kegiatan penangkapan yang dilakukan. Akibatnya ketika harga komoditas perikanan yang lain (seperti Teripang dan Gurita) sedang mengalami peningkatan harga maka nelayan akan lebih fokus untuk menangkap selain abalon. Kurangnya pasokan sampai ke pedagang juga terjadi karena transportasi yang kurang lancar antar daerah sehingga produk datang tidak tepat waktu. Lokasi produsen abalon yang berada di wilayah terpencil dengan akses sarana transportai yang belum memadai juga menjadi salah satu penyebabnya. 
Fluktuasi harga komoditas pada dasarnya terjadi akibat ketidakseimbangan antara kuantitas pasokan dan kuantitas permintaan yang dibutuhkan konsumen.jika terjadi kelebihan pasokan maka harga komoditas akan turun, sebaliknya jika terjadikekurangan pasokan. Proses pembentukan harga tersebut menunjukkan perilaku petani dan pedagang memiliki peranan penting karena mereka dapat mengatur volume penjualannya yang disesuaikan dengan kebutuhan konsumen (Irawan, 2007). Berdasarkan hal tersebut maka dapat dikatakan bahwa fluktuasi harga akan terjadi akibat kegagalan nelayan dan pedagang dalam mengatur volume pasokan sesuai dengan kebutuhan konsumen. Kondisi demikian disebabkan produksi abalon di kabupaten Buton yang terkonsentrasi hanya di Desa Bajo Bahari dan bergantung dari hasil tangkapan dari alam. Struktur produksi demikian tidak kondusif bagi stabilitas harga karena jika terjadi anomali produksi (musim puncak atau musim biasa) maka akan berpengaruh besar terhadap keseimbangan pasar abalon secara keseluruhan.

Perkembangan harga abalon yang terjadi secara langsung lebih dipengaruhi oleh peningkatan harga yang terjadi di tingkat konsumen. Perkembangan harga yang terjadi tidak selalu terkait dengan harga-harga sebelumnya (biaya produksi dan biaya pemasaran). Kondisi tersebut nampak ketika harga bahan bakar minyak (BBM) mengalami kenaikan tetapi harga jual sampai ke pedagang antar pulau tidak mengalami perubahan sementara biaya pemasaran meningkat. Oleh sebab itu perubahan harga yang terjadi sebagai akibat dari kurangnya informasi memungkinkan para pedagang melakukan diskriminasi harga yang menyebabkan harga di tingkat nelayan menjadi tidak wajar.

Harga yang dibayar konsumen dari sistem pemasaran seharusnya dapat mencerminkan secara tepat biaya pemasaran dan biaya produksi. Saluran pemasaran abalon yang ada di Kabupaten Buton didominasi oleh beberapa pedagang yang menentukan harga jual tinggi dengan harga beli dari produsen yang rendah, dari segi penetapan harga kondisi tersebut tidak efisien. Nelayan tidak memiliki bargaining position untuk menetapkan harga, sehingga seringkali nelayan terpaksa menjadipenerima harga (price taker). Sebaliknya pada level pedagang (pedagang pengumpul desa dan pedagang antar pulau) yang jumlahnya lebih sedikit akan cenderung memiliki kekuatan untuk mempengaruhi harga.

QE Journal | Vol.04 - No.02 June 2015 - 91 
Pada saat musim paceklik, musim dimana harga abalon umumnya tinggi akibat kekurangan pasokan, nelayan tidak akan mendapatkan keuntungan dari kenaikan harga. Keterbatasan modal yang dimiliki menyebabkan nelayan tidak memiliki kemampuan untuk menyediakan infrastruktur penyimpanan hasil produksinya. Sehingga nelayan umumnya menjual seluruh hasil produksinya sekaligus saat musim puncak (panen). Nelayan juga dihadapkan pada posisi fungsi penawaran yang inelastis, dimana nelayan tidak dapat meningkatkan hasil produksinya pada saat terjadi kenaikan harga abalon. Kondisi tersebut disebabkan sifat abalon yang memiliki waktu-waktu tertentu dimana hasil tangkapan nelayan banyak (musim). Akibatnya kenaikan harga pada saat musim paceklik sepenuhnya dinikmati oleh pedagang perantara.

Perkembangan harga abalon di Kabupaten Buton digambarkan berdasarkanhasil analisis data pada harga jual rata-rata abalon per bulan di tingkat pedagang antar pulau. Data harga jual abalon pada tingkat pedagang pengumpul desa tidak digunakan dalam analisis karena, pedagang pengumpul desa tidak selalu melakukan aktivitas penjualan setiap bulannya. Sehingga untuk mengetahui perkembangan harga di pasaran digunakan harga pembelian dari pedagang antar pulau yang menjadi tujuan penjualan pedagang pengumpul. Data harga rata-rata bulanan abalon di tingkat pedagang antar pulau dari bulan Januari tahun 2013 sampai bulan Juli tahun 2015). Data tersebut diolah dengan menggunakan software SPSS versi 19. Dari hasil analisis tersebut diperoleh persamaan garis trendharga abalon sebagai berikut:

$$
\mathrm{Y}=349946,217+(-9501,808) \mathrm{X}
$$

Keterangan :

$\mathrm{Y}=$ Harga jual Abalon $(\mathrm{Rp} / \mathrm{kg})$

$\mathrm{X}=$ Waktu (Bulan)

Hasil analisis menunjukkan bahwa nilai $\mathrm{F}$ hitung sebesar 16.754 pada taraf nyata 5 persen $(\alpha=0,05)$ dengan tingkat signifikansi 0,000pada taraf kesalahan $5 \%(0,05)$. Oleh karena itu tingkat signifikansi $\mathrm{F}$ hitung $(0,000)$ lebih kecil dari $\alpha=0,05$. Hasil tersebut menunjukkan bahwa variabel waktu $(\mathrm{X})$ berpengaruh nyata terhadap harga jual abalon $(\mathrm{Y})$.

Koefisien determinasinya $\left(R^{2}\right)$ sebesar 0,366berarti bahwa 36,6\% keragaman variabel perkembangan harga abalon dapat dijelaskan oleh keragaman 
waktu, sisanya 63,4\% dijelaskan oleh variabel lain yang tidak dimasukan dalam model. Koefisien korelasi (R) sebesar0,605 menunjukkan bahwa perkembangan harga abalon $(Y)$ berhubungan dengan perubahan waktu.

Tabel 1. Analisis Varians Regresi Linear Sederhana Pengaruh Waktu Terhadap Harga Jual Abalondi Kabupaten Buton Tahun 2015

\begin{tabular}{llllll}
\hline Model & $\begin{array}{l}\text { Derajat } \\
\text { Bebas }\end{array}$ & $\begin{array}{l}\text { Jumlah } \\
\text { Kuadrat }\end{array}$ & $\begin{array}{l}\text { Kuadrat } \\
\text { Tengah }\end{array}$ & Fhitung & Signifikansi \\
\hline Regresi & 1 & 31407307589 & 31407307589 & 16.754 & $0.000^{\mathrm{n}}$ \\
Residu & 29 & 54364869830 & 1874650684 & & \\
Total & 30 & 85772177419 & & & \\
\hline $\mathrm{R}$ & $=0,605$ & & & & \\
$\mathrm{R}^{2}$ & $=0,366$ & & & & \\
\hline
\end{tabular}

Keterangan $\mathrm{n}=$ Berpengaruh nyata pada $\alpha=0.05$

Tabel 2. Nilai Parameter Regresi Linear Sederhana Pengaruh Waktu Terhadap Harga Jual Abalondi Kabupaten Buton Tahun 2015

\begin{tabular}{llll}
\hline Model & Koefisien Regresi (b) & thitung & Signifikansi \\
\hline Waktu (Bulan) & -9501.808 & -4.093 & $0.000^{\mathrm{n}}$ \\
\hline Konstanta (a) $=349946.217$ & & \\
\hline \multicolumn{2}{l}{ Keterangan $\mathrm{n}=$ Berpengaruh nyata pada $\alpha=0.05$}
\end{tabular}

Berdasarkan Tabel 2 dapat dijelaskan pengaruh variabel waktu terhadap harga jual abalon. Nilai konstanta (a) sebesar 349946,217 dengan tingkat signifikansi 0,000 lebih kecil dari $\alpha(0,05)$, berarti bahwa konstanta a berpengaruh nyata terhadap perkembangan harga abalon.Dengan demikian jika nilai variabel bebas bernilai nol, maka harga jual abalon sebesar Rp. 349946,- per kilogram.

Nilai koefisien regresi (b) variabel waktu sebesar -9501,808 dan Thitung sebesar -4.093, dengan tingkat signifikansi sebesar 0.000 lebih kecil dari $\alpha$ $(0,05)$. Nilai tersebut menunjukkan bahwa variabel waktu mempunyai hubungan negatif dan berpengaruh nyata terhadap perkembangan harga. Nilai koefisien regresi sebesar -9501,808berarti bahwa, setiap peningkatan waktu sebesar satu periode (bulan) maka akan menurunkan harga jual abalon sebesarRp. 9.501 per kilogram. Kondisi tersebut disebabkan hasil tangkapan nelayan meningkat menjelang akhir tahun (memasuki musim panen). Menjelang akhir tahun supply abalon ke pedagang antar pulau meningkat sekitar $>100 \%$. Peningkatan jumlahabalon yang dipasarkan 
tersebut menyebabkan naiknya harga jual abalon akibat mekanisme pasar. Kecenderungan harga yang semakin menurun tersebut juga disebabkan oleh ukuran cangkang abalon yang ditangkap nelayan setiap tahun cenderung relatif kecil $(<7 \mathrm{~cm})$. Ukurang cangkang tersebut menyebabkan porduk abalon yang dipasarkan tidak sesuai dengan keinginan konsumen akibatnya harga jual abalon mengalami penurunan.

Peramalan perkembangan harga abalon di Kabupaten Buton untuk waktu lima bulan mendatang dapat dilakukan setelah variabel a (konstanta) dan $b$ (koefisien regresi) diketahui. Prediksi perkembangan harga abalon dapat dilihat pada Tabel 3.

Tabel 3. Prediksi Perkembangan Harga Jual Abalon di Kabupaten Buton Tahun 2015

\begin{tabular}{lllll}
\hline No. & Bulan & Tahun & X & Trend Harga $(\mathrm{Rp} / \mathrm{kg})$ \\
\hline 1. & Agustus & 2015 & 16 & 197930 \\
2. & September & 2015 & 17 & 188429 \\
3. & Oktober & 2015 & 18 & 178928 \\
4. & November & 2015 & 19 & 169427 \\
5. & Desember & 2015 & 20 & 159926 \\
\hline
\end{tabular}

Tabel 3 menunjukkanbahwa peramalan harga jual abalon selama kurun waktu bulan Agustus sampai Desember tahun 2015, mengalami penurunan harga. Pada bulan Agustus tahun 2015harga jual abalon pada tingkat pedagang pengumpul desa di Kabupaten Buton diprediksi sebesar Rp. 197930 per kilogram dan akan mengalami penurunan sampai Desember 2015 hingga harganya Rp. 159.926 per kilogram. Secara statistik dapat dikatakan bahwa harga abalon beberapa bulan mendatang akan memiliki kecendrungan mengalami penurunan. Kecendrungan penurunan harga tersebut diperkuat oleh pernyataan pedagang pada saat wawancara yang mengungkapkan bahwa harga jual abalon rata-rata tiap tahun mengalami penurunan. Penurunan harga abalon dikarenakan pada periode Agustus Desember terjadinya peningkatan jumlah abalon yang dijual pedagang pengumpul (produksi nelayan). Jumlah produksi abalon yang meningkat membuat para pedagang menurunkan harga beli. Selain itu penurunan harga juga terjadi dikarenakan permainan pedagang antar pulau yang sengaja membuat kondisi yang menyebabkan harga abalon di tingkat nelayan dan pedagang pengumpul desa menurun. Cara tersebut dilakukan

QE Journal | Vol.04 - No.02 June 2015 - 94 
dengan mengemukakan kecurigaan bahwa produk abalon yang dijual nelayan menggunakan bahan kimi berbahaya seperti hidrogen peroxide dan formalin.

\section{Elastisitas Transmisi Harga}

Elastisitas transmisi harga digunakan untuk menjelaskan perbandingan persentase perubahan harga ditingkat nelayan (Pf) dengan persentase perubahan harga ditingkat pedagang terakhir(Pr). Analisis elastisitas memberikan gambaran bagaimana harga yang dibayarkan konsumen akhir ditransmisikan kepada produsen. Analisis elastisitas transmisi harga pada penelitian ini bertujuan untuk mengetahui respon harga abalon ditingkat nelayan jika terjadi perubahan harga ditingkat pedagang antar pulau. Dari hubungan tersebut, secara tidak langsung dapat diperkirakan tingkat keefektifan suatu informasi pasar, bentuk struktur pasar dan efisiensi pemasaran abalon. Downey dan Erickson (1987) dalam Rahmi dan Arif (2012), menyatakan bahwa efisiensi penetapan harga berkaitan dengan keefektifan harga dalam mencerminkan biaya keluaran yang bergerak melalui sistem pemasaran. Harga yang dibayar konsumen dari sistem pemasaran harus mencerminkan secara tepat biaya pemasaran dan biaya produksi.

Analisis elastisitas transmisi harga dalam penelitian ini menggunakan model regresi linear sederhana, yaituPf $=\alpha+\beta \operatorname{Pr}+\varepsilon$. Pada umumnya nilai elastisitas transmisi harga lebih kecil dari satu, artinya jika volume dan harga input konstan maka perubahan harga relatif di tingkat pedagang terakhir tidak akan melebihi perubahan harga relatif ditingkat nelayan (Sudiyono, 2001). Data harga jual pada tingkat nelayan penangkap dan pedagang antar pulau(tersaji pada Lampiran 13) dianalisis menggunakan software SPSS version 20. Berdasarkan hasil analisis tersebut diperoleh hasil analisis regresi sederhana yang dapat dilihat pada Tabel 4.

Tabel 4 menunjukkan koefisien determinasi $\left(R^{2}\right)$ regresi pengaruh harga jual abalon di tingkat pedagang antar pulau terhadap harga di tingkat nelayan sebesar 0,699berarti bahwa 69,9\% keragaman variabel harga jual abalon di tingkat nelayan dapat dijelaskan oleh keragaman harga jual abalon di tingkat pedagang antar pulau, sisanya30,1\%dijelaskan oleh variabel lain yang tidak dimasukan dalam model. Koefisien korelasi (R) sebesar0,836 (mendekati 1) menunjukkan bahwa harga jual abalondi 
tingkat pedagang antar pulau berhubungan dengan perubahan harga jual di tingkat nelayan.

Tabel 4. Analisis Varians Regresi Linear Sederhana Pengaruh Harga Jual Abalon di Tingkat Pedagang Antar Pulau Terhadap Harga Jual Abalon Pada Tingkat Nelayandi Kabupaten Buton Tahun 2015

\begin{tabular}{llllll}
\hline Model & $\begin{array}{l}\text { Derajat } \\
\text { Bebas }\end{array}$ & $\begin{array}{l}\text { Jumlah } \\
\text { Kuadrat }\end{array}$ & $\begin{array}{l}\text { Kuadrat } \\
\text { Tengah }\end{array}$ & Fhitung & Signifikansi \\
\hline Regresi & 1 & 302293350.5 & 302293350.5 & 65.049 & $0.000^{\mathrm{n}}$ \\
Residu & 28 & 130121129.1 & 4647183.18 & & \\
Total & 29 & 432414479.6 & & & \\
\hline $\mathrm{R}$ & $=0,836$ & & & & \\
$\mathrm{R}^{2}$ & $=0,699$ & & & & \\
\hline
\end{tabular}

Keterangan $\mathrm{n}=$ Berpengaruh nyata pada $\alpha=0.05$

Tabel 5. Nilai Parameter Regresi Linear Sederhana Pengaruh Harga Jual Abalon di Tingkat Pedagang Antar Pulau TerhadapHarga Jual AbalonPada Tingkat Nelayan Tahun 2015

\begin{tabular}{|c|c|c|c|c|}
\hline Model & & Koefisien Regresi (b) & thitung & Signifikansi \\
\hline $\begin{array}{l}\text { Harga } \\
\text { Pulau }\end{array}$ & Pedagang Antar & 0.794 & 8.065 & $0.000^{\mathrm{n}}$ \\
\hline
\end{tabular}

Konstanta (a) $=-174411.06$

Keterangan $\mathrm{n}=$ Berpengaruh nyata pada $\alpha=0.05$

Berdasarkan Tabel 5dapat dijelaskan pengaruh variabel harga jual abalon pedagang antar pulau terhadap harga jual abalon di tingkat nelayan. Nilai konstanta (a) sebesar -174411.06 dengan tingkat signifikansi 0,000 lebih kecil dari $\alpha(0,05)$, berarti bahwa konstanta a berpengaruh nyata terhadap harga jual abalon di tingkat nelayan.Dengan demikian jika nilai variabel bebas (harga pedagang antar pulau) bernilai nol, maka harga jual abalon menurun sebesar Rp. 174411,- per kilogram.

Nilai koefisien regresi (b) variabel harga jual abalon pedagang antar pulau sebesar 0,794 dan Thitung sebesar 8.065, dengan tingkat signifikansi sebesar 0.000 lebih kecil dari $\alpha(0,05)$. Nilai tersebut menunjukkan bahwa variabel harga jual abalon pedagang antar pulau mempunyai hubungan positif dan berpengaruh nyata terhadap harga abalon di tingkat nelayan. Nilai koefisien regresi sebesar 0,794 berarti bahwa, setiap peningkatan harga pedagang antar pulau sebesar satu rupiah maka akan meningkatkan 
harga jual abalon di tingkat nelayan sebesar 0,794 atau kenaikan harga abalon pada pedagang antar pulau Rp. 1000 per kilogram akan menyebabkan peningkatan harga di tingkat nelayan sebesar Rp. 794 per kilogram.

Persamaan regresi linear sederhana harga di tingkat pedagang antar pulau dengan harga di tingkat nelayan dapat ditulis sebagai berikut:

$$
\begin{aligned}
& \text { Pf }=\alpha+\beta \operatorname{Pr} \\
& \text { Pf }=-174411,067+0.794 \mathrm{Pr}
\end{aligned}
$$

Keterangan :

Pf = Harga jual abalon di tingkat nelayan

Pr = Harga jual abalon di tingkat pedagang antar pulau

Pengujian terhadap model dilakukan menggunakan persamaan di atas. Nilai koefisien regresi dari persamaan tersebut digunakan untuk menentukan nilai elastisitas transmisi harga abalon. Nilai elastisitas transmisi harga pedagang antar pulau terhadap harga nelayan penangkap abalon. Elastisitas transmisi harga abalon dapat dilihat pada Tabel 6 .

Tabel 6. Elastisitas Transmisi Harga (Et) Abalon di Kabupaten Buton Tahun 2015

\begin{tabular}{lllll}
\hline Koefisien Regresi (b) & R Square $\left(\mathrm{R}^{2}\right)$ & $\mathrm{Pf}(\mathrm{Rp} / \mathrm{kg})$ & $\operatorname{Pr}(\mathrm{Rp} / \mathrm{kg})$ & Nilai Et \\
\hline 0,794 & 0,699 & 22398 & 248000 & 0,11 \\
\hline
\end{tabular}

Keterangan :

Pf = Harga jual abalon ditingkat nelayan

$\operatorname{Pr}=$ Harga jual abalon ditingkat pedagang antar pulau

Tabel 6 menunjukkan nilai elastisitas transmisi harga (Et) pada saluran pemasaran abalon di Kabupaten Buton sebesar 0,11. Nilai tersebut menunjukkan bahwa jika terjadi kenaikan harga jual abalon pada tingkat pedagang antar pulau atau konsumen akhir sebesar 1\% maka harga jual abalon pada tingkat nelayan akan mengalami peningkatansebesar $0,11 \%$. Nilai elastisitas transmisi harga sebesar 0,11 menunjukkan bahwa laju perubahan harga jual abalon pada saluran pemasaran abalon di Kabupaten Buton tidak elastis. Perubahan harga jual abalon di tingkat pedagang antar pulau tidak dapat ditransmisikan secara sempurna sampai ke tingkat nelayan penangkap. Kondisi tersebut disebabkan oleh adanya kerjasama 
diantara para pedagang dalam menentukan harga pembelian dari nelayan. Sehingga perubahan harga pembelian antar pedagang relatif tidak berbeda.

Pedagang abalon yang jumlahnya sedikit juga menyebabkan transmisi harga abalon tidak elastis. Pedagang menciptakan ketergantungan dari nelayan untuk hanya memasarkan hasil tangkapannya kepada para pedagang tertentu. Cara tersebut biasanya ditempuh pedagang dengan memberikan modal kepada para nelayan dengan kesepakatan nelayan harus menjual hasil tangkapannya kepada pedagang yang memberikan pinjaman modal.

\section{SIMPULAN DAN SARAN}

\section{Simpulan}

Perkembangan harga abalon pada pedagang antar pulau dari bulan Januari 2013 sampai Juli 2015 mengalami penurunan sebesar Rp. 9.501 perbulan. Harga jual abalon akan menurun sampai bulan Desember 2015, hingga harganya mencapai Rp. 159.926 per kilogram.

Nilai elastisitas transmisi harga (Et) abalonkurang dari satu yaitu sebesar 0,11, menandakan saluran pemasaran abalon di Kabupaten Buton belum efisien.Laju perubahan harga jual abalon ditingkat pedagang antar pulau lebih besar daripada laju perubahan harga di tingkat nelayan.

\section{Saran}

Mengembangkan daerah sentra produksi baru yang lebih tersebar secara regional sehingga dapat mengurangi fluktuasi harga yang disebabkan oleh anomali produksi.

Pemerintah hendaknya dapat memberikan informasi pasar (perkembangan harga), meliputi kegiatan pengumpulan data harga dan analisis serta publikasi data tersebut agar terjadi transparansi informasi pasar.

\section{DAFTAR PUSTAKA}

Assauri, S, 1988. Manajemen Produksi dan Operasi. Lembaga Penerbit Fakultas Ekonomi Universitas Indonesia, Jakarta.

Hasyim, A.I., 2003. Tataniaga Pertanian. Fakultas Pertanian. Universitas Lampung, Bandar Lampung.

QE Journal | Vol.04 - No.02 June 2015 - 98 
Irawan, B., 2007. Fluktuasi Harga, Transmisi Harga dan Marjin Pemasaran Sayur dan Buah. Badan Litbang Pertanian Kementrian Pertanian. Jurnal Analisis Kebijakan Pertanian Volume 5 (358-373).

Kuncor, M. 2008. Statistik Deskriptif untuk Manager. Lembaga Penerbit Fakultas Ekonomi Universitas Indonesia, Jakarta.

Leighton, D.L, 2008. Abalon Hatchery Manual. Aquaculture Technical Section, Aquaculture Development Division. Co. Dublin, Ireland.

Litaay, M., 2005. Peranan Nutrisi dalam Siklus Reproduksi Abalon. Jurnal Oseana Volume30 (1-7).

Priyadi,U., I. Susantun dan A.S. Dewanta, 2004. Analisis Distribusi Ayam Broiler di Propinsi Daerah Istimewa Yogyakarta. Jurnal Ekonomi Pembangunan Volume 9, Nomor 2 (193-205).

Rahmi, E., dan B. Arif, 2012. Analisis Transmisi Harga Jagung sebagai Bahan Baku Pakan Ternak Ayam Ras di Sumatera Barat. Jurnal Peternakan Indonesia Volume 14, Nomor 2 (343-348).

Setyono, D.E.D, 2004. Abalone (Haliotis asinina L) : A Prospesctive Species for Aquaculture in Indonesia. Oseana Volume 29 (25-30).

2007. Prospek Usaha Budidaya Kekerangan di Indonesia. Oseana, Volume 32 (33-38).

2009. Abalon: Teknologi Pembenihan. Lembaga Ilmu Pengetahuan Indonesia Press, Jakarta.. 2010. Abalon: Teknologi Pembenihan. ISOI, Jakarta.

Sudiyono, A. 2001. Pemasaran Produk Pertanian. Universitas Muhammadiyah Malang Press, Malang. 